\section{Peroxidases of Selected Fruits and Vegetables and the Possible Use of Ascorbic Acid as an Antioxidant}

\author{
G. Préstamo and $\mathbf{P}, \mathbf{M}$ anzano \\ Instituto del Frío, Consejo Superior de Investigaciones Científicas, Ciudad \\ Universitaria, Madrid 28040, Spain
}

Additional index words. isozymes, potato (Solanum tuberosum), carrot (Daucus carota), tomato (Lycopersicon esculentum), kiwifruit (Actinidia deliciosa), cauliflower (Brassica oleracea), green beans (Phaseolus vulgaris), horseradish (Armoracia rusticana)

\begin{abstract}
The various isozymes of peroxidase of a range of vegetables and kiwifruit were compared using sodium dodecyl sulfate polyacrylamide gel electrophoresis followed by specific activity staining. Peroxidase isozymes were determined in potato (Solanum tuberosum L.), carrot (Daucus carota L.), tomato (Lycopersicon esculentum Mill.), kiwifruit [Actinidia deliciosa (A. Chev.) C.F. Liang et A.R. Ferguson], cauliflower [Brassica oleracea (Botrytis group)], green beans (Phaseolus vulgaris L.), and horseradish (Armoracia rusticana Gaertn, Mey Scherb.). There was only one isozyme in cauliflower (70 kDa), two in kiwifruit (45-43 kDa), and a range of isozymes (120-36 kDa) in horseradish. Ascorbic acid inhibited peroxidase activity in the extracts.
\end{abstract}

The role peroxidases play in the living plant is not completely understood, although they have been associated with cell wall biosynthesis, response to injury, disease resistance, and wound repair.

Peroxidases consist of a family of isozymes (Shanon et al., 1966) that catalyze the same or similar reactions. All of these enzymes contain identical heme groups but differ in the precise composition of the glycoprotein (Gaspar et al., 1982). Peroxidases are found in almost all vegetables; horseradish peroxidase is the most extensively studied. Many major isozymes have been found using electrophoresis (Hoyle, 1977).

The molecular weights of the peroxidases produced by cultivated tobacco (Nicotiana tabacum L.) cells $(103,90,67$, and $46 \mathrm{kDa})$ are similar to those produced by potato tuber (105, $94,56.5$, and $48.5 \mathrm{kDa})$. The similarity of peroxidases in potato and tobacco, both solanaceous plants, reflects the genetic similar-

\footnotetext{
Received for publication 23 Aug. 1991. Accepted for publication 31 July 1992. This work was supported by the Consejo Superior de Investigaciones Científicas. Proyecto 88GE. ref ALI 88-0180. Plan Nacional de Technología de Alimentos. The cost of publishing this paper was defrayed in part by the payment of page charges. Under postal regulations, this paper therefore must be hereby marked advertisement solely to indicate this fact.
}

ity between these related plants (Decedue et al., 1984). Peroxidases normally increase in activity and number during ripening. Thomas et al. (1981) found five isozymes in tomato fruit.

Our studies on peroxidase were focused on the isoperoxidase found in some fruit and vegetable extracts. These studies are of interest to the food industry, since the activity of this enzyme may influence fruit and vegetable quality.

Potato tubers, carrot roots, tomato fruit, kiwifmit, cauliflower heads, and green bean pods were obtained from the local market. Horseradish peroxidase was purchased from Sigma, Madrid. The extracts were prepared from three sample specimens, and duplicates were used to measure peroxidase activity and protein content.

A sample of each type of produce was blended in $50 \mathrm{~mm}$ tris. $\mathrm{HCl} \mathrm{pH} 7.8$ buffer at a $1: 2$ ratio $(\mathrm{w} / \mathrm{v})$. The extract was centrifuged at $10,000 \times g$ for $10 \mathrm{~min}$ at $4 \mathrm{C}$ to remove debris. The clarified supernatant was used to determine the various isozymes using sodium dodecyl sulfate polyacrylamide gel electrophoresis (SDS-PAGE) and to measure peroxidase activity using spectrophotometry. Ascorbic acid was used as a natural antioxidant.

Peroxidase activity. Peroxidase activity was measured with a spectrophotometer at $460 \mathrm{~nm}$ using $O$ - dianisidine as a chromogenic indicator (Préstamo, 1989). Peroxidase activity was expressed in units of peroxidase per milligram protein. A unit of peroxidase activity was defined as an increment of 0.001 of absorbance/min.

Antioxidant experiment. In the peroxidase activity reaction, 2 to $25 \mu \mathrm{l}$ ascorbic acid (15 $\left.\mathrm{mg} \cdot \mathrm{ml}^{-1}\right)$ was substituted by buffer following the same reaction to determine peroxidase activity. Ascorbic acid was added until peroxidase was inhibited completely.

Ascorbic-acid content. The ascorbic acid content of the fruits and vegetables was determined following the AOAC method (1984).

Electrophoresis. SDS-PAGE was performed according to Laemmli (1970). Acrylamide/bisacrylamide (12\% w/v) was used in a mini-slab gel system. Electrophoresis was carried out at 4C using $175 \mathrm{~V}$ for $90 \mathrm{~min}$. The electrode buffer was glycine-tris $(\mathrm{pH} \mathrm{8.3)}$. Samples of $15 \mu \mathrm{l}$ (4 to $12 \mu \mathrm{g}$ protein) were loaded into each well at the top of the gel. For activity staining, gels were soaked for $30 \mathrm{~min}$ at $20 \mathrm{C}$ in $50 \mathrm{~mm}$ sodium acetate buffer, $\mathrm{pH} 6$. Gels were then treated with $0.1 \%$ hydrogen peroxide and $0.25 \% o$ - dianisidine. The appearance of dark brown bands was caused by peroxidase activity and indicated the presence of a peroxidase isoenzyme in the gel.

The molecular weight standards used in these studies were phosphorylase $b(94 \mathrm{kDa})$, albumin $(67 \mathrm{kDa})$, ovalbumin $(43 \mathrm{kDa})$, carbonic anhydrase $(30 \mathrm{kDa})$, trypsin inhibitor (20kDa), and $a$ - lactalbumin $(14.4 \mathrm{kDa})$. Total protein concentration was measured by dye binding (Bradford, 1976).

Among all the fresh produce assayed, kiwifruit had the highest ascorbic acid concentration (Table 1). Kiwifruit and potatoes had the lowest peroxidase activity, while green beans had the highest (Fig. 1). When determining proper blanching time, researchers should take this activity level into account. Interestingly, fruits and vegetables with lower peroxidase activity are more suitable for freezing than canning.

Table 1. Ascorbic acid content in selected fruits and vegetables.

\begin{tabular}{lc}
\hline Product & $\begin{array}{c}\text { Ascorbic acid } \\
(\mathrm{mg} / 100 \mathrm{~g} \text { fresh wt })\end{array}$ \\
\hline Potato & 32.50 \\
Green beans & 21.25 \\
Cauliflower & 50.00 \\
Carrot & 8.50 \\
Tomato & 15.50 \\
Kiwifruit & 84.00 \\
\hline
\end{tabular}


There seems to be a relationship among some of the major peroxidase isozymes (Fig. 2). Four of the extracts contain a $70 \mathrm{kDa}$ band, three extracts contain a 55 and $43 \mathrm{kDa}$ band, and two contain 40-36 kDa bands. Cauliflower, an inflorescence, contains only one isozyme $(70 \mathrm{kDa})$; kiwi, a fruit, two isozymes $(45-43 \mathrm{kDa})$; and horseradish, a root, contains many isozymes. The rest of the extracts have a range of isozymes between 120 and $36 \mathrm{kDa}$.

Peroxidase Units/mg protein

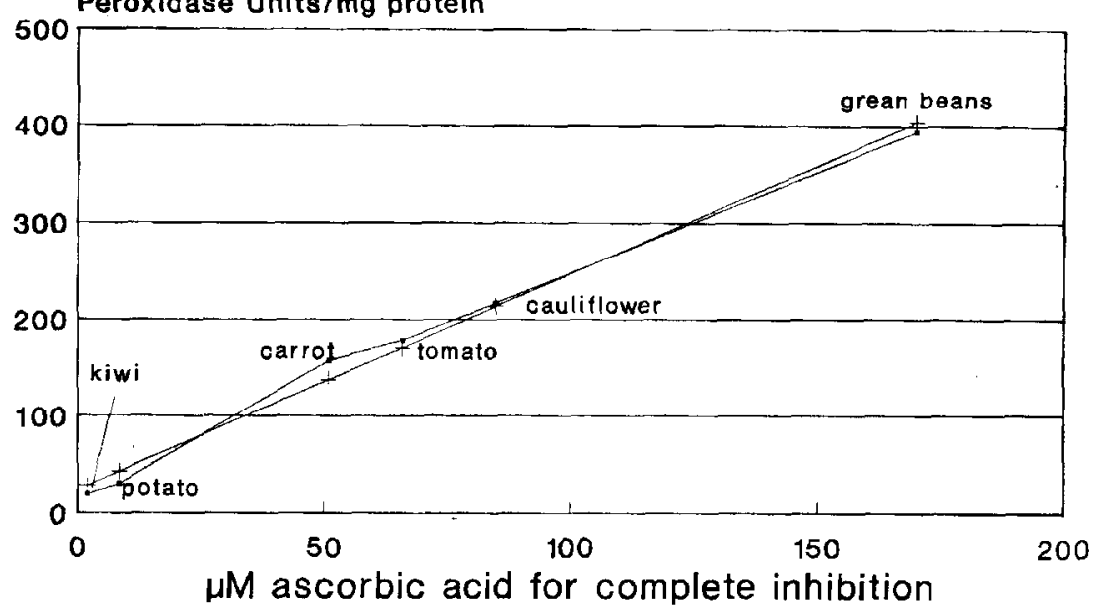

- Experimental values $\rightarrow$ Linear regression

Fig. 1. Peroxidase activity and micromoles of ascorbic acid needed to inactivate peroxidase in various fruits and vegetables.

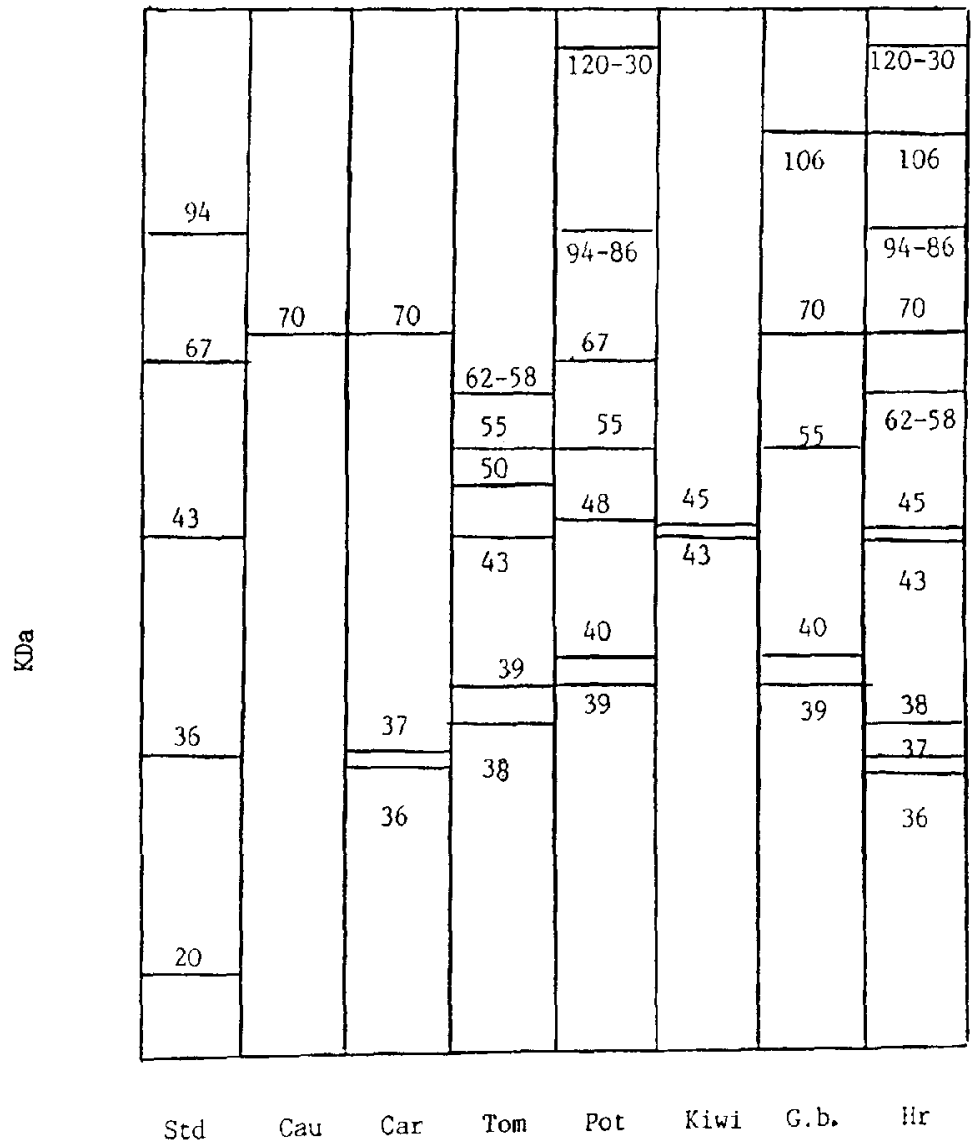

Fig. 2. Peroxidase isozymes of various fruit and vegetable extracts. $\mathrm{Std}=$ standard; $\mathrm{Cau}=$ cauliflower; $\mathrm{Car}$

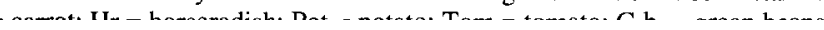

at the green stage, whereas more isozymes appeared as ripening progressed (data not shown).

We also determined the effectiveness of ascorbic acid, a natural antioxidant, inactivation of peroxidase. Addition of antioxidants has become increasingly popular as a means of increasing the shelf life of food. Recently, however, the safety of synthetic antioxidants has been questioned. Ascorbic acid has been used as a peroxidase inhibitor (Shinkle and Jones, 1988).

Between 2 and $170 \mu \mathrm{M}$ ascorbic acid was required to inhibit peroxidase activity completely in all assayed extracts (Fig. 1). Kiwifruit needed the lowest, while green beans required the highest ascorbic acid concentration. As more ascorbic acid was added, the peroxidase activity reaction was delayed 75 to $120 \mathrm{~min}$.

Peroxidase activity does not depend only on the number of isozymes present, since there is only one isozyme in cauliflower extract that exhibited high activity and two isozymes in kiwifruit that showed the lowest peroxidase activity. The $\mathrm{Km}$ and $\mathrm{V}_{\max }=$ for these isoenzymes must also be taken into account.

Based on our observations, we postulate that products with high peroxidase activity must be blanched or treated with antioxidant to decrease isozyme activity. Those fruits and vegetables that exhibit low peroxidase activity and mainly contain low-molecular-weight isozymes need not be blanched, however, they can be treated with antioxidants if needed. This relationship may explain, in part, why carrots can be stored at $-18 \mathrm{C}$ as a frozen product in acceptable condition for 9 months without blanching and antioxidant addition (Espinosa et al., 1984). In the case of kiwifruit, similar results were obtained (Cano et al., 1989).

In addition, using ascorbic acid as an antioxidant is not only completely safe for human consumption but could enhance the vitamin $\mathrm{C}$ content of certain fruits and vegetables.

\section{Literature Cited}

AOAC. 1984. Official methods of analysis. 14th ed. Assn. Offic. Analytical Chem., Washington, DC.

Bradford, M. 1976. A rapid and sensitive method for the quantitation of microgram quantities of protein utilizing the principle of protein-dye binding. Anal. Biochem. 72:248-254.

Cano, P., C. Fuster, and G. Préstamo. 1989. Suitability to freezing of four Spanish kiwi fruit cultivars. Proc. Intl. Conf. Technical Innovation in Freezing and Refrigeration of Fruits and Vegetables, Davis, Calif. p. 262-267.

Decedue, J.C., J.S. Roger, and R. Borchert. 1984 Molecular weight differences among potato peroxidases. Phytochemistry 23(4):723-727.

Espinosa, J., G. Préstamo, C. Fuster, and W. Canet. 1984. Tolérance, temps-temperature de légumes congelés; carottes. Proc. XVI Intl. Congr. Refr. III, Paris. p. 561-567.

Gaspar, TH.C., T. Thorpe, and H. Greppin. 1982. Peroxidases 1970-1980. A survey of their biochemical and physiological roles in higher plants. Université de Genéve, Centre de Botanique. p. 889-1112. 
Hoyle, M.C. 1977. High resolution of peroxidaseindolacetic acid oxidase isoenzyme from horseradish by isoelectric focusing. Plant Physiol. 60:787-793.

Laemmli, U.K. 1970. Cleavage of structural proteins during the assembly of the head of bacteriophage T4. Nature (London) 227:680-685.

Préstamo, G. 1989. Peroxidase of kiwifruit. J. Food Sci. 54(3):760.

Roberts, E., T. Kutchan, and P.E. Kolattukudy.
1988. Cloning and sequencing of cDNA for highly anionic peroxidase from potato and the induction of its mRNA in suberizing potato tubers and tomato fruits. Plant Molec. Biol. 11:15-26.

Rothan, C. and J. Nicolas. 1989. Changes in acidic and basic peroxidase activities during tomato fruit ripening. HortScience 24(2):340-342.

Shanon, L.M., K. Kay, and J.Y. Lew. 1966. Peroxidase isoenzymes from horseradish root. I. Isola- tion and physical properties. J. Biol. Chem. 241:2166-2172.

Shinkle, J.R. and R.L. Jones. 1988. Inhibition of stem elongation in cucumis seedling by blue light requires calcium. Plant Physiol. 86:960966.

Thomas, R.L., J.J. Jen, and Ch.V. Morr. 1981. Changes in soluble and bound peroxidase-IAA oxidase during tomato fruit development. J. Food Sci. 47:158-161. 